\title{
パルスレーザー推進による静止遷移軌道への単段打ち上げシステムの可能性*1 Feasibility for a Single-Stage-to-Orbit Launch to a Geosynchronous Transfer Orbit by Pulse Laser Propulsion
}

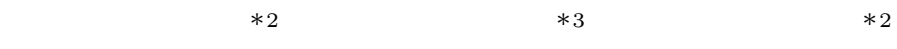 \\ Hiroshi Katsurayama, Kimiya Komurasaki and Yoshihiro Arakawa
}

Key Words : Laser Propulsion, Space Transportation, Launch Cost

\begin{abstract}
An air-breathing pulse laser powered launcher has been proposed as an alternative to conventional chemical launch systems. The trajectory from the ground to a geosynchronous transfer orbit by pulse laser propulsion is calculated by modeling the thrust during pulsejet, ramjet and rocket flight modes, and the launch cost is estimated. The results show that the pulse laser powered launcher can transfer $0.085 \mathrm{~kg}$ payload per $1 \mathrm{MW}$ beam power to a geosynchronous orbit, and the cost becomes quarter of existing systems if one can divide a single launch into 22,500 multiple launches.
\end{abstract}

1. は じめ に

太陽発電衛星のようないくつかの革新的な宇宙開発計画 は , 化学ロケットによる従来型打ち上げシステムが非常に 高コストであるため, 経済的成立性が乏しい.例えば , 出力 1 GW 級の太陽発電衛星を GEO (Geosynchronous Orbit) に建設するために，H2A ロケットにより $10^{4}$ トンの資材を

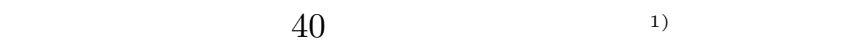
より低コストな打ち上げシステムが必要となるが , 弚の一 つとしてパルスレーザー推進を用いた打ち上げシステムが 考えられている.このシステムでは, エネルギーは地上の レーザー基地から供給され，また，推進剂には大気を用い ることができるため, 高ぺイロード比を達成でき，コスト を削減できると考えられている．

第 1 図にこれまでに提案されている空気吸い込み型パル スレーザー推進機 2 ) を示す (機体サイズは $100 \mathrm{MW}$ クラス のレーザーを用いた場合の代表的な値) .この推進機では， 伝送されたレーザービームは放物型のスパイクノズルによ り集光され，プラズマが生成される．このプラズマは続く レーザービームを吸収しながら膨張し，爆風波を駆動する この爆風波がノズル上を伝播する際に機体は推力を得る .

第 2 図にパルスレーザーを用いた打ち上げシステムの概 念図を示す . 打ち上げ初期段階では，機体は空気取込口を 閉じ，背面から吸排気を行う「パルスジェット」モードで 飛行する．次に，機体が十分に加速してラム圧縮を利用で きるようになったら, 空気取込口を開け, 前面から空気を 取り込む「ラムジェツト」モードに移行する.最後に，機体

\footnotetext{
*1 C) 2006 日本航空宇宙学会

平成 17 年 7 月 22 日原稿受理

*2 東京大学大学院航空宇宙工学専攻

*3 東京大学大学院新領域創成科学研究科先端エネルギー工学専攻
}

が高高度に達し，十分に空気を取り込めなくなったら，空 気取込口を再び閉じ, 搭載している水素を推進凧として使 う「ロケット」モードに移行する．これらの三つのモード を用いて，機体は軌道到達速度まで加速する．

レーザー推進を用いた軌道への打ち上げ可能性の検討は これまでにもなされてきたが ${ }^{3 \sim 6)}$, 弚れらの多くはエネル ギ一変換効率を固定している.しかし, 空気吸い込み型推 進機の場合, エネルギー変換効率は飛行軌道に依存するこ とは明らかである . 光こで本研究では , パルスジェットモー ドでは実験值をもとに推進性能をモデル化し , ラムジェッ トモードでは実験值は存在しないので, 我々が以前に行っ た CFD 解析 ${ }^{7)}$ を用いて飛行軌道上の推進性能を求め, 口 ケットモードでは同樣の理由で解析解を用いて推進性能を 求める.この手法により現実的な推力モデルを提案し , こ れらの推力モデルを用いて , パルスレーザー推進機の GTO (Geosynchronous Transfer Orbit) への軌道解析を行い， ペイロード比とコストを見積もって打ち上げシステムとし ての実現可能性を検討する .

\section{2. 光のハイウェイ ${ }^{2)}$}

パルスレーザー打ち上げシステムには, 平均出力数 $100 \mathrm{MW}$ から数 GW クラスのレーザー発振基地が必要で あり, Kare ${ }^{8)}$ の見積もりによれば, 谷のようなレーザー発 振基地の建設費は, レーザー発振器が大部分を占め, 冷却 系および電力供給系などの割合は小さい .このため, シス テムを成立させるには, 第一にレーザー発振器のコストを 抑えることが重要であり, 現在のところ最も安価である半 導体レーザーをアレイ化して使用 ${ }^{8,9)}$ することが有望であ る.また，コスト面から 1 基のレーザー基地で打ち上げる ことが現実的である．

次に, ビーム伝送に関して懸念される点について述べる 
と，まずビーム広がりについては, 開口径 $1 \mathrm{~m}$, 波長 $1 \mu \mathrm{m}$ のガウスビームであると仮定すれば，弚の広がり全角は $1.2 \times 10^{-6} \mathrm{rad}$ であり，本論文で考える伝送距離 $500 \mathrm{~km}$ 程 度の場合は , ビームは径 $1.19 \mathrm{~m}$ にしか広がらず問題にはな らない. 大気中の分子による吸収は, レーザー波長を適切 に選ぶことによって最小限にすることができる（波長 0.4 $\sim 1.3 \mu \mathrm{m}$ がよい ${ }^{10)}$ ). 大気の非線形効果 (大気の屈折率の 変化, サーマルブルーミング, レイリー散乱, ラマン散乱 およびミ一散乱）によるビームの広がり，減衰および屈折 については，NASA の ORION 計画 ${ }^{10)}$ (軌道上のデブリを パルスレーザービームで打ち落とす計画）において行われ

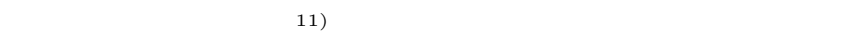
して決まる上限のレーザーパワー密度以下でビーム伝送を 行えば非線形効果を無視できる．

大気乱流により生じるビーム中心の振れ回り現象は，天 文台が造られているような快晴の日が多く大気の摇らぎの 少ない山の山頂 (例えばハワイのマウナケア山は雲がない 日が $90 \%$ に近い) に射場を建設し，雲一つない大気の安定 した時を見計らって打ち上げることで防ぐことができる．ま た , 機体形状を工夫することで , 機体軸が常にビームの中

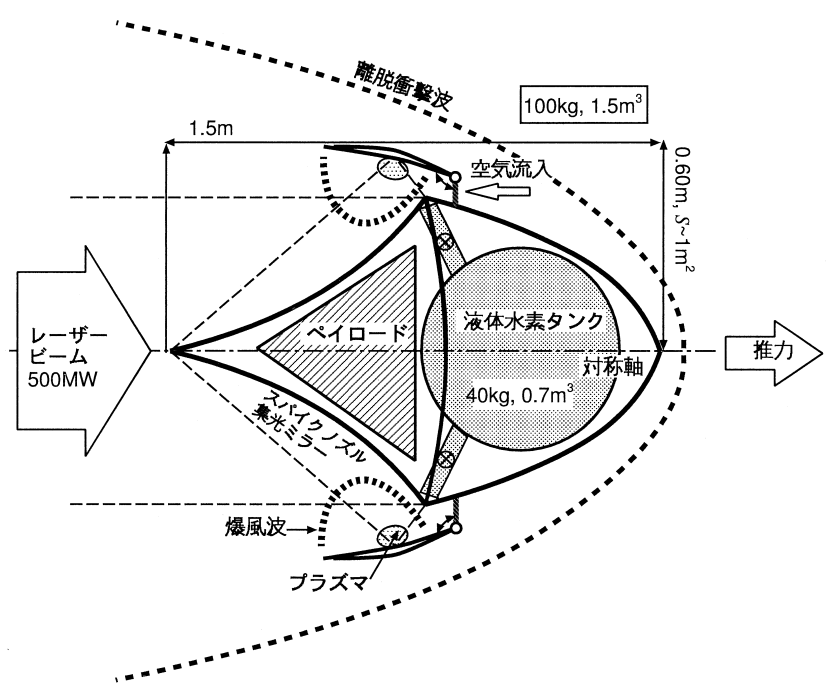

第 1 図 空気吸い込み型パルスレーザー推進機 ${ }^{2)}$

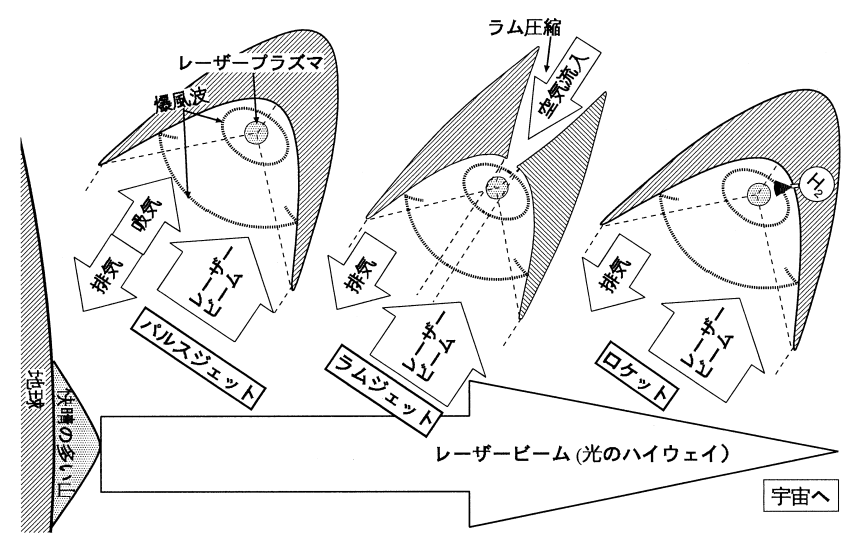

第 2 図 パルスレーザー打ち上げシステム
心軸と一致するように推力ベクトルおよびトルクが生じて 空力的な動安定が得られる研究 ${ }^{12)}$ が進んでおり，この技術 を用いるとビームと機体の飛行方向を共に地面に垂直に維 持することができる．従って，飛行中の機体の捕捉および 機体へのビーム指向を行う必要はなく，レーザーにより地 上から垂直に光のハイウェイ ${ }^{2)}$ (第 2 図) を作ってやれば， 弚れに沿って機体を宇宙に運ぶことができる。

\section{3. 提案する GEOへの打ち上げ軌道}

ビーム伝送に要求される条件を考慮すると，光のハイウェ イに沿って機体を短い距離で垂直に加速して GTO に投入 する第 3 図に示すような打ち上げ軌道が望ましい .この軌 道では，機体はレーザー推進によって赤道付近で打ち上げ られ，急速に $\Delta v_{\mathrm{L}}$ 増速する. 兴の後，二の増速を最大限に 利用するため，慣性飛行によりいったん GEO を越え，アポ ジ点まで達する．この後は，ホーマン型移行を行い，搭載 キックモーターによりアポジ点において $\Delta v_{\mathrm{a}}$ の増速を行っ て機体を GTO に投入し，ペリジ点において $\Delta v_{\mathrm{p}}$ の減速を 行い機体を GEO に投入する.

第 4 図に必要となる搭載キックモーターとレーザー推進の 増速を示す.レーザー推進により $\Delta v_{\mathrm{L}}=10.85 \mathrm{~km} / \mathrm{s}$ の増速 を行えば，搭載キックモーターによる増速は $\left|\Delta v_{\mathrm{a}}\right|+\left|\Delta v_{\mathrm{p}}\right|=$ $2 \mathrm{~km} / \mathrm{s}$ ですむ .この速度増分は, ペイロード側に搭載され た電気推進などの高比推力の推進機で行われるが，例えば 比推力 $I_{\mathrm{sp}, \mathrm{EP}}=2000 \mathrm{~s}$, 構造係数 $\varepsilon_{\mathrm{EP}}=0.1$ とし, 太陽電 池はペイロード重量とみなすと，上段部のペイロード比は

$$
\lambda_{\mathrm{EP}}=\left[1-\frac{1-\exp \left(-\frac{\left|\Delta v_{\mathrm{a}}\right|+\left|\Delta v_{\mathrm{p}}\right|}{g I_{\mathrm{sp}, \mathrm{EP}}}\right)}{1-\varepsilon_{\mathrm{EP}}}\right]=0.89
$$

となる．ここで， $g$ は重力加速度である．

なお，GEO へエネルギー最小で打ち上げる場合のエネ ルギー増分を $\Delta E_{\mathrm{GEO}}, \Delta v_{\mathrm{L}}=10.85 \mathrm{~km} / \mathrm{s}$ の増速を行い 第 3 図の軌道を経て GEO へ打ち上げる場合のレーザー推 進によるエネルギー増分を $\Delta E_{\mathrm{L}}$ とすると，第 3 図の軌道

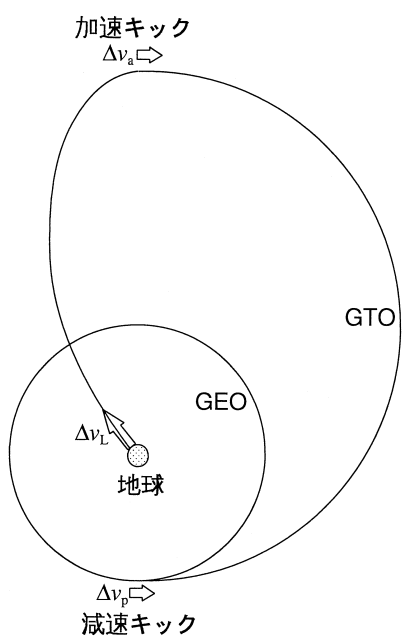

第 3 図提案する GEO への打ち上げ軌道 


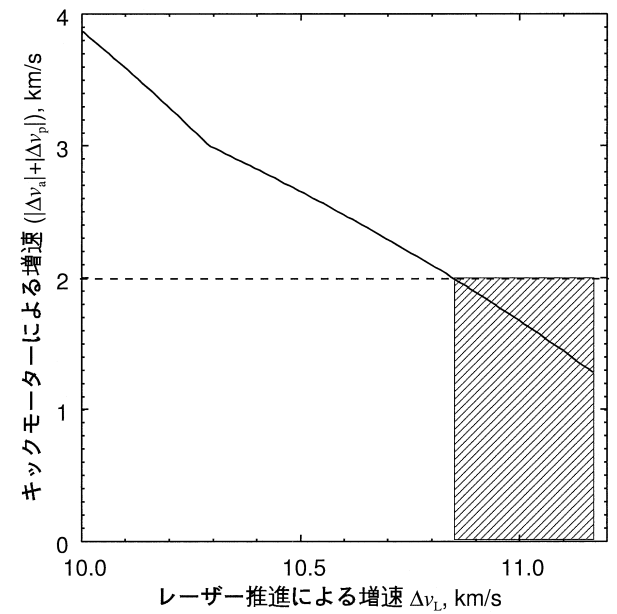

第 4 図＼cjkstart搭載キックモーターとレーザー推進に必要な増速

をとることによるエネルギー損失は

$$
\left(\Delta E_{\mathrm{L}}-\Delta E_{\mathrm{GEO}}\right) / \Delta E_{\mathrm{L}}=2 \%
$$

にすぎない .

4. パルスレーザー打ち上げ機の推進性能モデリング

パルスレーザー打ち上げ機はパルスジェット , ラムジェッ 卜，ロケットとモードを切り替えて $\Delta v_{\mathrm{L}}=10.85 \mathrm{~km}$ の増 速を達成する．この節では，产の軌道を計算する際に使わ れる各モードの推進性能をモデル化する .

なお , パルスジェットモードでは, 弚の吸排気過程がほぼ 音速で伝播する希薄波に支配されている ${ }^{13)}$ ため，他のモ一 ドに比べて 1 サイクルが長く ${ }^{7)}$ ，これがパルスレーザーの 繰り返し周波数 $\nu_{\mathrm{p}}$ を決定することがわかっている . また， ノズル長さとレーザーエネルギーのスケーリング則に関し ては，投入レーザーエネルギーに依存して決定される爆風 波特性長さ $R_{\mathrm{bw}}^{*}{ }^{13)}$ に対して, 4.1 節で述べる運動量結合係 数が最大になる最適ノズル長さ

$$
R_{\mathrm{n}, \mathrm{opt}}=0.4 R_{\mathrm{bw}}^{*}
$$

が存在する ${ }^{13)}$. 弚こで，吸気および排気に关れ攵れ $\left(R_{\mathrm{n}, \mathrm{opt}} / c_{\mathrm{a}}\right)$ 時間かかると仮定し，さらに相似解 ${ }^{14)}$ を用い て爆風波がノズルを伝播し終わる時間を見積り，乥れらの 合計が 1 サイクルに要する時間と仮定すると, 最大の $\nu_{\mathrm{p}}$ は

$$
\nu_{\mathrm{p}, \max } \sim c_{\mathrm{a}} /\left[R_{\mathrm{n}, \mathrm{opt}}\left(\sqrt{0.4^{3} \gamma / \xi_{0}^{5}}+2\right)\right]
$$

と概算できる.ここで， $c_{\mathrm{a}}$ は䨌囲気の音速， $\gamma=1.4$ は理 想気体空気の比熱比， $\xi_{0}=1.03$ は $\gamma$ に依存して決まる定 数である.例えば， $R_{\mathrm{n}, \mathrm{opt}}=7 \mathrm{~cm}$ のノズルを用いた CFD 解析 ${ }^{13)}$ によれば， 1 サイクルに要する時間は $500 \mu \mathrm{s}$ (つま り周波数は $2000 \mathrm{~Hz}$ ) である.一方, 式 (4) で決まる周波 数は $\nu_{\mathrm{p}}=2177 \mathrm{~Hz}$ となり，よい目安となる.しかし，1サ イクルが終わって，ノズル内圧力が回復した後も，集光点 付近の爆発中心付近には, 低密度で高温なプラズマが取り

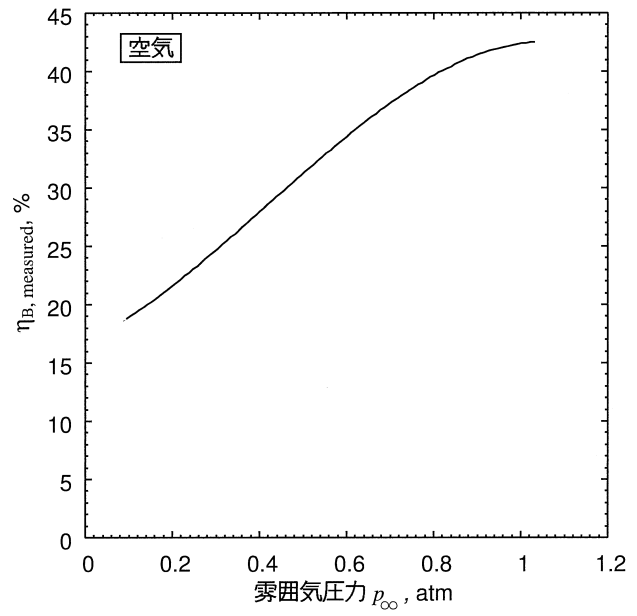

第 5 図 減圧空気中で測定された $\eta_{\mathrm{B}}{ }^{15)}$

残されたままであり7， $\nu_{\mathrm{p}, \max }$ でパルスレーザーを運転す ると，性能低下を招く可能性がある .このため，実際には $\nu_{\mathrm{p}, \max }$ より小さい周波数で運転することになる.この点は 今後の研究課題である.

4.1 運動量結合係数と爆風波エネルギー変換効率 レー ザー推進では性能指針として, 1 パルスのレーザーエネル ギーに対する力積の比である運動量結合係数

$$
C_{\mathrm{m}}=\int_{1 \text { pulse }} F \mathrm{~d} t / E_{\mathrm{L}}
$$

が使われる こここで, $t$ は時間， $F$ は推力,$E_{\mathrm{L}}$ はパルスあ たりのレーザーエネルギーである、気体に吸収されたレー ザーエネルギーは次式で表される爆風波エネルギー $E_{\mathrm{B}}$ に 変換される.

$$
\begin{aligned}
E_{\mathrm{B}}= & \int_{V_{\mathrm{B}}}\left[\rho\left(e^{\mathrm{t}+\mathrm{r}}+\boldsymbol{u} \cdot \boldsymbol{u} / 2\right)\right. \\
& \left.-\rho_{0}\left(e^{\mathrm{t}+\mathrm{r}}+\boldsymbol{u} \cdot \boldsymbol{u} / 2\right)_{0}\right] \mathrm{d} V
\end{aligned}
$$

ここで， $V_{\mathrm{B}}$ は爆風波に囲まれた体積， $\rho$ は密度,$e^{\mathrm{t}+\mathrm{r}}$ は並 進と回転の内部エネルギー, $\boldsymbol{u} \cdot \boldsymbol{u} / 2$ は運動エネルギーで ある．また，添字 0 はレーザー入射前の物理量を表す．な お，レーザーエネルギー吸収に伴い新たに分子内部に蓄え られる振動や電子励起エネルギーは, 化学ポテンシャルエ ネルギーと同樣に圧力仕事として使用することができない ため， $E_{\mathrm{B}}$ から除外される． $E_{\mathrm{B}}$ だけが $F$ に寄与するので， $C_{\mathrm{m}}$ は爆風波エネルギー変換効率

$$
\eta_{\mathrm{B}}=E_{\mathrm{B}} / E_{\mathrm{L}}
$$

に比例し，推進性能をモデル化するためには $\eta_{\mathrm{B}}$ が必要とな る . パルスジェットとラムジェットモードについては , 第 5 图に示す空気中で害験的に求められた $\eta_{\mathrm{B}}{ }^{15)}$ が存在し，こ れを圧力 $p$ によりフィッティングしたものを用いた .

$$
\begin{aligned}
\eta_{\mathrm{B}, \text { measured }}(p)= & 0.167+0.196 p / p_{\mathrm{s}} \\
& +0.370\left(p / p_{\mathrm{s}}\right)^{2}-0.309\left(p / p_{\mathrm{s}}\right)^{3}
\end{aligned}
$$


ここで, $p_{\mathrm{s}}=1 \mathrm{~atm}$ は海面上での標準圧力である . なお， 大気組成の变化が $\eta_{\mathrm{B}}$ に与える影響については, 大気組成は 高度 $100 \mathrm{~km}$ 以上て変化し始める ${ }^{16)}$ のに対して , ラムジェッ トモードで飛行する高度は $40 \mathrm{~km}$ 以下であるため考慮する 必要はない。

ロケットモードについては, 平面の Chapman-Jouguet デトネーション関係式と化学反応平衡計算を組み合わせた 数值モデル17) を用いて, 水素燃料中でのレーザー支持デト ネーション波 ${ }^{18)}$ の伝播を解き，得られた $\eta_{\mathrm{B}}=23.5 \%$ を用 いた .

4.2 パルスジェットモードパルスジェットモードでは海 面上での運動量結合係数 $C_{\mathrm{m}, \mathrm{s}}$ が , ライトクラフト型2,19), ベルノズル型20,21)，円錐ノズル型22)，LITA 型23)につい て測定されており，ノズル形状や $E_{\mathrm{L}}$ に依存して 100〜 $500 \mathrm{~N} / \mathrm{MW}$ の範囲を持つ。しかし，空気吸い込み型であ るライトクラフト型では, $E_{\mathrm{L}}$ に対しては $C_{\mathrm{m}}$ はほとんど 変化しない, 19). 本研究では, 機体形状に空気吸い込み型 のライトクラフト型を用いると仮定しているため, 弚の典 型的な值である $C_{\mathrm{m}, \mathrm{s}}=200 \mathrm{~N} / \mathrm{MW}^{2)}$ を用いて，

$$
C_{\mathrm{m}}\left(p_{\infty}\right)=C_{\mathrm{m}, \mathrm{s}}\left[\eta_{\mathrm{B}, \text { measured }}\left(p_{\infty}\right) / \eta_{\mathrm{B}, \text { measured }}\left(p_{\mathrm{s}}\right)\right]
$$

とし,$C_{\mathrm{m}}$ の雾囲気压力 $p_{\infty}$ の変化による影響を考慮した 4.3 ラムジェットモードラムジェットモードでは, 我々 の以前の研究 ${ }^{7}$ ににおいて, CFD 解析 (熱的平衡・化学非平 衡の空気 11 種プラズマモデル，爆風波は爆発源モデルに より駆動) を用いてライトクラフト型機体の $C_{\mathrm{m}}$ を計算し， これが $E_{\mathrm{L}}$ にほぼ無関係であることがわかっている．弚こ で, この CFD 解析を用いて飛行マッ八数 $M_{\infty}$, 雾囲気密 度 $\rho_{\infty}$ に対して 16 対を選び計算を行って第 6 図に示す $C_{\mathrm{m}}$ のマップを作成し，これを

$$
\begin{aligned}
C_{\mathrm{m}}\left(M_{\infty}, \rho_{\infty}\right)= & {\left[0.04 M_{\infty}^{2}-1.81 M_{\infty}+19.00\right] } \\
& \times\left[0.35\left(\log _{10} \rho_{\infty}\right)^{2}+5.01\left(\log _{10} \rho_{\infty}\right)\right. \\
& +13.06]
\end{aligned}
$$

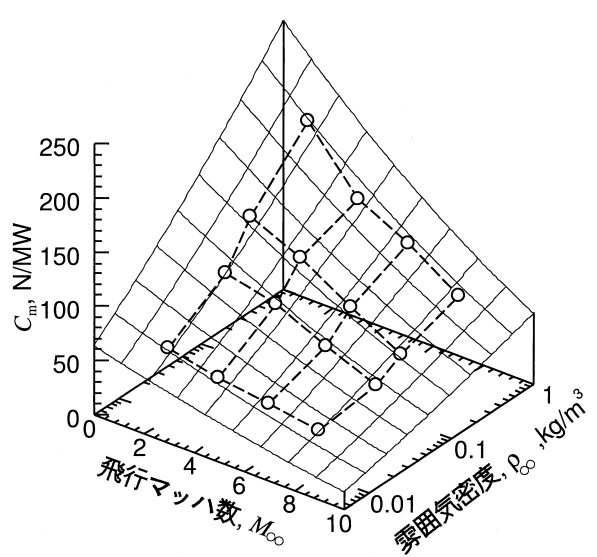

第6图 ラムジェットモードでの $C_{\mathrm{m}}$ のマップ
の関数によりフィッティングして飛行軌道解析で用いた .な お，爆発源のモデル化に必要となる $\eta_{\mathrm{B}}$ は式 (8) を用いた . $C_{\mathrm{m}}$ は, $\rho_{\infty}$ の減少と共に機体捕獲流量か減少するため小さ くなり， $M_{\infty}$ の増加と共に爆風波がエンジン内に留まれる 時間が減少するため小さくなる．

4.4 ロケットモードロケットモードでは, 機体はほぼ 真空中を飛行するため, 推力はノズル膨張比だけに依存す ると見なすことができる．乥こで, Simons らの円錐ノズ ル内での相似解モデル ${ }^{24)}$ を用いて $C_{\mathrm{m}}$ を見積もった .この モデルではノズル内から真空中に膨張している水素推進剂 中での爆風波伝播を仮定しており，

$$
C_{\mathrm{m}}=\sqrt{2 \dot{m}_{\mathrm{p}} \eta_{\mathrm{B}} / P_{\mathrm{L}}} \sin ^{2} \alpha /[2 \pi(1-\cos \alpha)]
$$

となる.ここで, $\dot{m}_{\mathrm{p}}$ は水素質量流量， $P_{\mathrm{L}}$ は時間平均され たレーザーパワー， $\alpha$ はノズル半頂角である.$\alpha$ はライト クラフト型機体の值にほぼ等しい $30^{\circ}$ を用いた .

4.5 モード切り替え パルスジェットからラムジェット へのモード切り替えは, 機体が加速し, 爆風波が空気取入 口より上流に遡らなくなった時に行われるべきである．し かし，このタイミングを正確にモデル化するためには，さ まざまな $E_{\mathrm{L}}$ と飛行条件に対して CFD 解析を行わなくて はならない，乥こで, 本研究では, 最も安全側の条件とし て，機体内の流れがレーザー加熱によって熱閉塞しなくなっ た時にモード切り替えを行うことにし，第 7 图に示すエン ジンサイクルを使ってこれを判定した .このサイクルでは， まず空気が位置 $\# 0$ において実効空気取込口断面積

$$
A_{0}=S_{\mathrm{v}} \times \text { C.A.R }
$$

を経て取り込まれる.ここで， $S_{\mathrm{v}}$ は機体の最大断面積， C.A.R は捕獲流量比である. 次に\# 0 から\#1 において空 気は外部圧縮される .

$$
u_{1}=\eta_{\mathrm{d}} u_{0}
$$

ここで, $u$ は空気の流速である .ディフューザー効率 $\eta_{\mathrm{d}}$ および C.A.R はライトクラフト型機体について CFD 解 析により算出した值 ${ }^{25)}$ を用い, 弚れ光れ $M_{\infty}$ に依存して $\eta_{\mathrm{d}}=0.64 \sim 0.72\left(M_{\infty}\right.$ と共に減少 $)$, C.A.R $=0.31 \sim 0.71$ ( $M_{\infty}$ と共に増加) の範囲て変化する.\#1 から $\# 2$ におい て，空気は等エントロピー的に膨張される.これは，\#3に おける熱閉塞を遅らせるためである . 最後に\# 3 において 空気は等積的にレーザー加熱される. \#3 でのマッハ数は

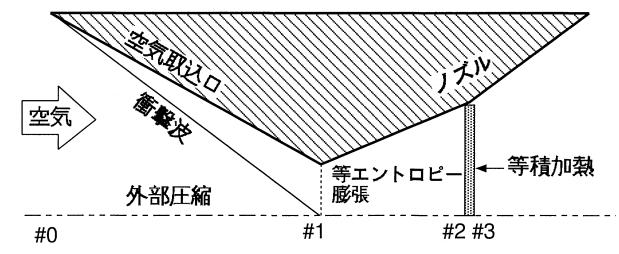

第7図 モード切り替え判定のためのエンジンサイクル 
パルスレーザー推進による静止遷移軌道への単段打ち上げシステムの可能性 (葛山 浩・小紫公也・荒川義博)

$$
\begin{aligned}
M_{3} & =\frac{u_{3}}{\sqrt{\gamma R T_{3}}} \\
& =\frac{u_{2}}{\sqrt{\gamma R\left[T_{2}+\eta_{\mathrm{B}} \eta_{\text {trans }} P_{\mathrm{L}} /\left(C_{\mathrm{p}} \dot{m}_{\text {air }}\right)\right]}}
\end{aligned}
$$

となる .ここで, $\dot{m}_{\mathrm{air}}$ は機体捕獲流量,$T$ は温度 $, R, C_{\mathrm{p}}$ は 気体定数, 定圧比熱で, 弚れ光れ理想気体空気の值を用いた。 また， $\eta_{\text {trans }}$ はレーザービームの伝送効率である $. M_{3}=1$ となった時 , パルスジェットモードをラムジェツトモードに 切り替える。

ラムジェットモードでは, 空気取込口から取り込まれる 空気流量が大気密度の減少により高度と共に減少し, 最終 的には空力抵抗と推力が釣り合うようになり，機体の加速 度がゼロになる. そ光の時, ラムジェットからロケットモー ドに切り替える。

\section{5. 飛行軌道とペイロード比}

垂直打ち上げ軌道は，岡体の運動方程式

$$
m_{\mathrm{v}} \frac{\mathrm{d} v}{\mathrm{~d} t}=\bar{F}-\frac{1}{2} \rho_{\infty} v^{2} S_{\mathrm{v}} C_{\mathrm{d}}-m_{\mathrm{v}} g
$$

を 4 次精度ルンゲクッタ法により解いて求めた .ここで, $v$ は機速， $m_{\mathrm{v}}$ は機体重量である.飛行条件は軌道に沿って決 められる . 抵抗係数 $C_{\mathrm{d}}$ はライトクラフト型機体について $\mathrm{CFD}$ 解析により算出された值 ${ }^{25)}$ を用い， $M_{\infty}$ に依存して $C_{\mathrm{d}}=0.15 \sim 0.64$ の範囲をとる. 時間平均推力 $\bar{F}$ は各々の モードでの $C_{\mathrm{m}}$ を用いて，

$$
\bar{F}=C_{\mathrm{m}} \eta_{\text {trans }} P_{\mathrm{L}}
$$

となる .ここで, 発振器に十分大口径のレーザーフェイズ ドアレイを用いるとした場合のビーム中心ローブに含まれ るエネルギー割合の理論予測値 $\eta_{\text {trans }}=72 \%{ }^{9)}$ を伝送効率 として用い, 大気による吸収の影響は無視した。なお，こ の值は伝送距離に依存しない値である．

軌道解析の結果, ペイロード比 $\lambda$ は

$$
\lambda=\left\{1-\int_{\text {Rocket mode }} \dot{m}_{\mathrm{p}} \mathrm{d} t /\left[m_{\mathrm{v}, 0}\left(1-\varepsilon_{\mathrm{L}}\right)\right]\right\} \lambda_{\mathrm{EP}}
$$

により求められる．ここで， $m_{\mathrm{v}, 0}$ は初期機体重量である. $\varepsilon_{\mathrm{L}}$ はパルスレーザー推進機の構造係数で, パルスレーザー 推進機の構造の簡潔さを考慮して 0.1 とした .また，式 $(1)$ より $\lambda_{\mathrm{EP}}=0.89$ とした . 第 1 表に仮定した機体の諸元を 示す. $S_{\mathrm{v}} / m_{\mathrm{v}, 0}$ と $\dot{m}_{\mathrm{p}} / m_{\mathrm{v}, 0}$ は水素燃料タンクのサイズの 観点から決定したが，これらの值はまだ最適化されていな いものである .

第 8 図に特性ビームパワー $P_{\mathrm{L}} / m_{\mathrm{v}, 0}$ に対する飛行軌道と $\lambda$ を示す . $\lambda$ とラムジェットモードの飛行時間は $P_{\mathrm{L}} / m_{\mathrm{v}, 0}$ の

第 1 表 機体の諸元

\begin{tabular}{cc}
\hline$S_{\mathrm{v}} / m_{\mathrm{v}, 0}\left(\mathrm{~m}^{2} / \mathrm{kg}\right)$ & $\dot{m}_{\mathrm{p}} / m_{\mathrm{v}, 0}\left(\mathrm{~s}^{-1}\right)$ \\
\hline 0.01 & 0.01 \\
\hline
\end{tabular}

減少と共に減少し， $P_{\mathrm{L}} / m_{\mathrm{v}, 0}<1.47 \mathrm{MW} / \mathrm{kg}$ でラムジェッ トモードが利用できなくなる．ビーム伝送は最大 $400 \mathrm{~km}$, $160 \mathrm{~s}$ の伝送が必要となる。

第 9 図にビームパワー $1 \mathrm{MW}$ あたりに搭載可能 なペイロード重量 $m_{\text {payload }} / P_{\mathrm{L}}$ と $\lambda$ の $P_{\mathrm{L}} / m_{\mathrm{v}, 0}$ に 対する変化を示す. $\lambda$ は $P_{\mathrm{L}} / m_{\mathrm{v}, 0}$ と共に増加するが, $m_{\text {payload }} / P_{\mathrm{L}}$ は $\left(P_{\mathrm{L}} / m_{\mathrm{v}, 0}\right)_{\mathrm{opt}}=2.5 \mathrm{MW} / \mathrm{kg}$ において最 大值 $0.085 \mathrm{~kg} / \mathrm{MW}$ をとり, 光の時にレーザー発振器のコ ストは最小となる .

$\left(P_{\mathrm{L}} / m_{\mathrm{v}, 0}\right)_{\mathrm{opt}}=2.5 \mathrm{MW} / \mathrm{kg}$ の場合の飛行特性について， $C_{\mathrm{m}}$ および機体加速度の履歴を第 10 図に示し, 飛行動圧 $q$ およひ機体前面の淀み点での壁面温度 $T_{\mathrm{w}}$ の履歴を第 11 図 に示す． $T_{\mathrm{w}}$ は, Detra-Kemp-Riddell のモデル ${ }^{26)}$ から求 めた淀み点での加熱率と輻射冷却率が平衡になると仮定し て求めた壁面温度 27 )である.なお, Detra-Kemp-Riddell モデルにおいて必要となる機体前面の曲率半径は $0.5 \mathrm{~m}$ と

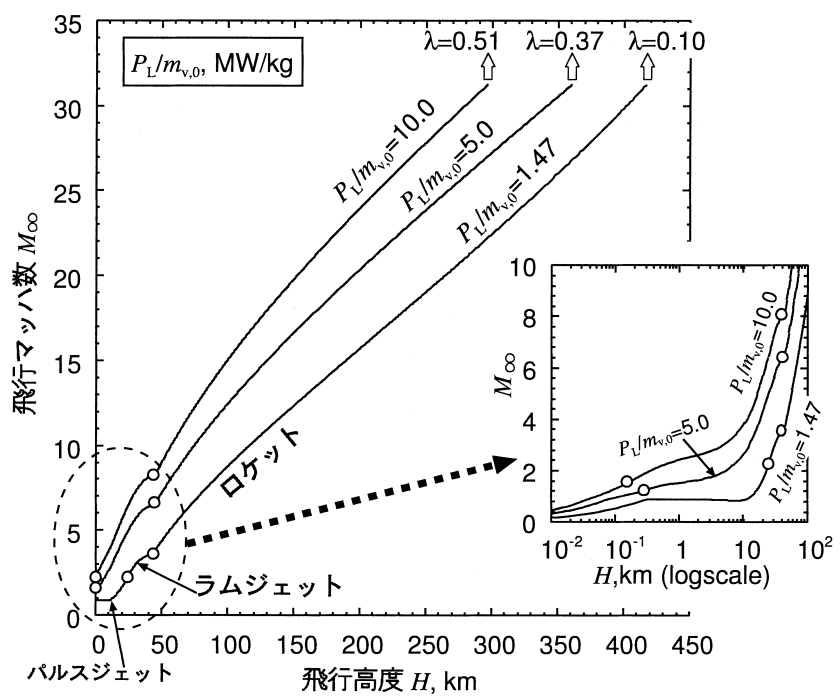

第 8 図 飛行マッハ数対飛行高度線図

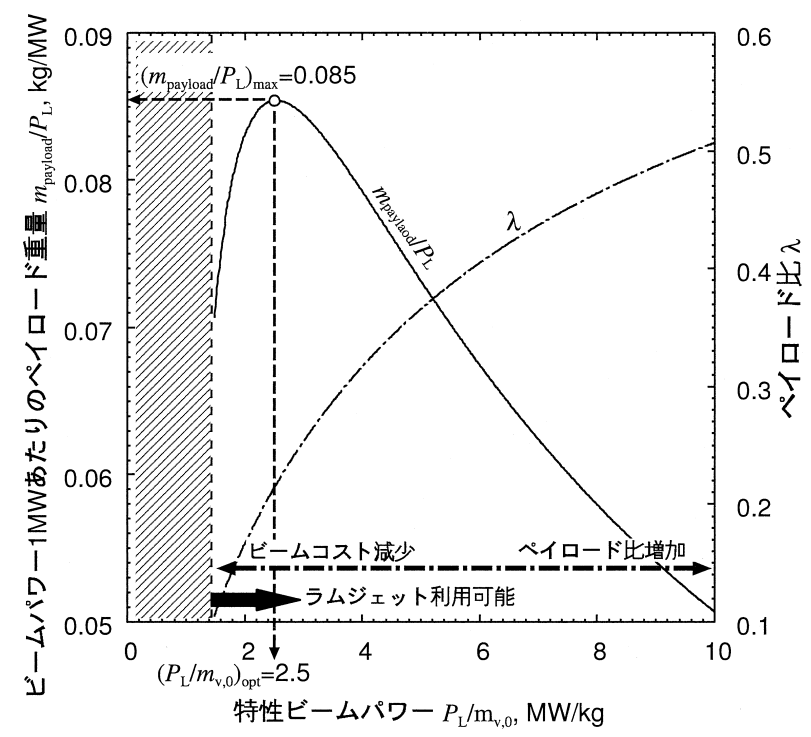

第 9 図 $m_{\text {payload }} / P_{\mathrm{L}}$ と $\lambda$ の $P_{\mathrm{L}} / m_{\mathrm{v}, 0}$ に対する変化 


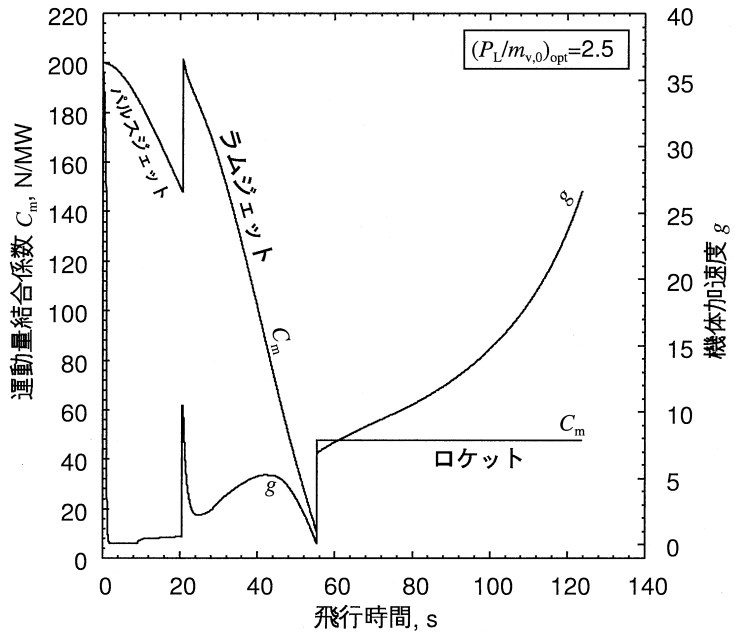

第 10 図 $C_{\mathrm{m}}$ と機体加速度の履歴

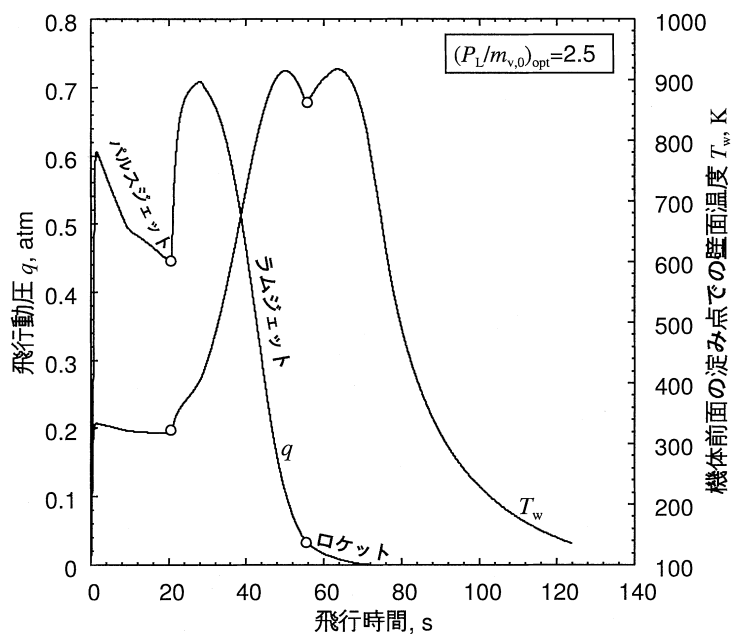

第 11 図 飛行動圧と機体前面の淀み点での壁面温度の履歴

仮定した。

パルスジェットモードとラムジェットモードでは $C_{\mathrm{m}}$ は 高度と共に減少する. 加速度に関しては , パルスジェット モードにおいて, 空力抵抗と推力が釣り合って加速度がほ ぼゼロになる領域がある．また，各モード開始時はいずれ も急激な加速を伴い, パルスジェット開始時には $35 g$ にな る.ロケットモードにおいて加速度が徐々に増加していく のは, 燃料消費に伴い機体重量が減少していくためである. このように加速度はかなり大きくなるが, 本研究では機体 に宇宙構造物建設のための材料を載せることを考えており， 弾道ミサイルなどでは $40 g$ を超えるもの（例えばアメリカ のジュピターIRBM , 液体燃料使用) もあるため, 人を乗 せなければ問題はない. 飛行動圧については, つねに $1 \mathrm{~atm}$ 以下であるので, 機体にかかる構造的な負荷も問題になら ない . 空力加熱については, 最大で $T_{\mathrm{w}}=920 \mathrm{~K}$ になるが (この時の加熱率は $40 \mathrm{~kW} / \mathrm{m}^{2}$ )，この程度なら特別な対策 は必要ない。
第 2 表 考慮したコスト

\begin{tabular}{cccc}
\hline$C_{\mathrm{LT}}(¥ / \mathrm{W})$ & $\eta_{\mathrm{DL}}(\%)$ & $C_{\mathrm{E}}(¥ / \mathrm{kWh})$ & $C_{\mathrm{VP}}(¥ / \mathrm{kg})$ \\
\hline $1,000^{8)}$ & $40^{8)}$ & 6 & $100,000^{29)}$ \\
\hline
\end{tabular}

6. 打ち上げコスト

パルスレーザー打ち上げ機を用いて GEO に $10^{4}$ ton の 太陽発電衛星を打ち上げるミッションを例にとり，コスト 評価を行う. 数 $100 \mathrm{MW}$ から数 GW のレーザー発振器の コストを算出するのは容易ではないが，白川ら ${ }^{28)}$ によれ ば, 現在高出力化の方法の一つとして注目されているのが， 既存の固体・ファイバーレーザーや半導体レーザーをアレ イ化し , コヒーレントカップリングにより大出カレーザー を得る方法である．光こで, 現在単位出力あたりの製造コ ストが最も安価な半導体レーザーのコヒーレントカップリ ングの技術を応用すると仮定して，発振基地のコストを見 積もつた．考慮したコストを第 2 表に示す. $C_{\mathrm{LT}}$ は単位出 カあたりのレーザー発振器のコストであり, 現在の半導体 レーザーの製造コスト8) である .レーザー冷却装置, 電力 供給装置, メンテナンス費などはレーザー発振器のコスト と比較して無視できるほど小さいと考えられるので考慮し ていない . $\eta_{\mathrm{DL}}$ は一般的な半導体レーザーのエネルギー変 換効率である ${ }^{8)} . C_{\mathrm{E}}$ は日本の一般的な電気代である.$C_{\mathrm{VP}}$ は単位機体重量あたりの機体製造費であり，ライトクラフ 卜型機体について見積もられたものである29).

商用衛星の現在の打ち上げコストと比較するために , パ ルスレーザー打ち上げ機のコストをレーザー発振器の償還 を含んだ形で

Launch cost

$\overline{\text { Payload mass }}$

$$
\begin{aligned}
& =\frac{\left(\frac{C_{\mathrm{LT}}}{n_{\mathrm{L}}}+\frac{C_{\mathrm{E}}}{\eta_{\mathrm{DL}}} t_{\text {flight }}\right) P_{\mathrm{L}}+C_{\mathrm{VP}} m_{\mathrm{v}, 0}}{m_{\text {payload }}} \\
& =\frac{\frac{C_{\mathrm{LT}}}{n_{\mathrm{L}}}}{\left(\frac{m_{\text {payload }}}{P_{\mathrm{L}}}\right)_{\max }}+\frac{\frac{C_{\mathrm{E}}}{\eta_{\mathrm{DL}}} t_{\text {flight }}}{\left(\frac{m_{\text {payload }}}{P_{\mathrm{L}}}\right)_{\max }}+\frac{C_{\mathrm{VP}}}{\lambda}
\end{aligned}
$$

と定義する . なお，一般に公開されている打ち上げコスト (例えば H $2 \mathrm{~A}$ の打ち上げあたり 80 億円) とは , 実はロケッ 卜製造費だけであることが多いため, 人件費などは省いた． ここで， $n_{\mathrm{L}}$ はペイロードを分割して打ち上げる回数であ る.式 (18) の 3 行目の右辺第 1 項はレーザー発振器コス 卜の償還，第 2 項は電気代，第 3 項は機体製作費にあたる . また，特性ビームパワーは $\left(P_{\mathrm{L}} / m_{\mathrm{v}, 0}\right)_{\mathrm{opt}}=2.5 \mathrm{MW} / \mathrm{kg}$ と して $\left(m_{\text {payload }} / P_{\mathrm{L}}\right)_{\text {max }}=0.085 \mathrm{~kg} / \mathrm{MW}$ を用いる . その 時，飛行時間は $t_{\text {flight }}=124 \mathrm{~s}$ および $\lambda=0.21$ である .

第 12 図にパルスレーザー打ち上げ機と現在の打ち上げシ ステム (コストは 80 億円/launch) の単位ペイロードあた りの打ち上げコストの $n_{\mathrm{L}}$ に対する変化を示す . $n_{\mathrm{L}}$ が $10^{3}$ 回より小さい場合はレーザー発振器のコストが支配的であ 


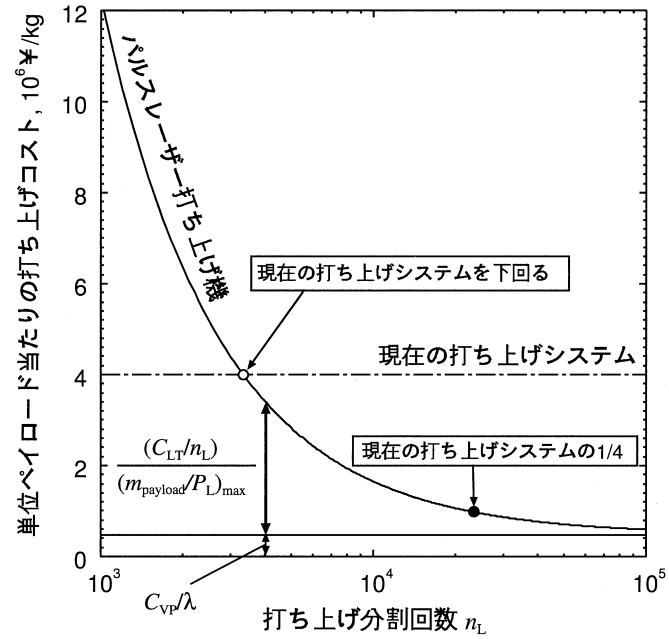

第 12 図 単位ペイロードあたりの打ち上げコストの $n_{\mathrm{L}}$ に対する変化

る.なお，電気代は無視できるほど小さい . $n_{\mathrm{L}}$ の増加と共 に打ち上げコストは減少し，3,300 回に分けて打ち上げる ことでレーザー発振器のコストを償還し，現在の打ち上げ システムと同等のコストとなる $. n_{\mathrm{L}}=22,500$ 回の場合， コストは現在の打ち上げシステムの $1 / 4$ 程度となり，もし $n_{\mathrm{L}}$ を $10^{5}$ よりも大きくできる場合は, コストはほぼ機体 制作費 (ペイロード $1 \mathrm{~kg}$ あたり 20 万円程度) のみとなる． 電気代はこの時点でも無視できるほど小さい .

結果として, $5 \mathrm{GW}$ クラスの出カのレーザー発振器を使 用できれば，打ち上げあたり約 0.5 ton の輸送能力があり， 20,000 回程度に分割することで $10^{4}$ ton の太陽発電衛星を 従来の輸送コストの $1 / 4$ て打ち上げることができると予測さ れる.さらに，機体の大量生産により $C_{\mathrm{VP}}=10,000 ¥ / \mathrm{kg}$ にコストダウンできれば, 太陽発電衛星などの打ち上げコ ストを現在より 1 桁以上安くすることができる .

なお，本研究で提案するパルスレーザー打ち上げシステ ムでは, 多くの小型機体を打ち上げるため，機体のデブリ 化が心配されるが, 提案している第 3 図の軌道では, アポ ジキック前にペイロードを切り離せば，機体は確実に地球 に引き寄せられ大気圏に突入し燃え尽きる .

$$
\text { 7. 結論 }
$$

パルスレーザーによる地上から $\mathrm{GTO}$ への打ち上げ軌道 を, パルスジェット, ラムジェットおよびロケットモードの 各推進性能をモデル化することで計算し，パルスレーザー 打ち上げ機が $1 \mathrm{MW}$ あたり $0.085 \mathrm{~kg}$ のペイロードを輸送可 能であることを示した . また , 現在の打ち上げシステムの コストを下回るためには, レーザー発振器のコストを償還 するため, ペイロードを 3,300 回に分割して打ち上げる必 要があり，22,500 回に分割して打ち上げれば，パルスレー ザー打ち上げ機は従来の $1 / 4$ 程度のコストが実現可能であ る.さらに，もし $10^{5}$ 回に分割して打ち上げるミッション があれば，パルスレーザー打ち上げ機はペイロード $1 \mathrm{~kg}$ あ たり 20 万円程度のコストを実現できる可能性がある．ま た，さらに多数の分割打ち上げや機体の大量生産により機
体コストを下げることにより，打ち上げコストは現在より 1 桁以上安くできる .

\section{考 文 献}

1) Collins, P.: The Promise of Electricity from Space for World Economic Development, Proc. 5th Int. Energy Conf., Vol. 3, 1993, pp. 50-59.

2) Myrabo, L. N.: World Record Flights of Beam-Riding Rocket Lightcraft: Demonstration of "Disruptive" Propulsion Technology, AIAA Paper 01-3798, 2001.

3) Toki, K.: Conceptual Study of Laser Direct Launch, J. Space Tech. Sci., 8 (1991), pp. 23-31.

4) Kare, J. T.: Trajectory Simulation for Laser Launching, Proc. 1986 SDIO/DARPA Workshop on Laser Propulsion, Vol. 2, 1986, pp. 61-77.

5) Humble, W. E. and Pierson, B. L.: Maximum-Payload Trajectories for a Laser-Propelled Launch Vehicle, J. Guid. Control Dynam., 18 (1995), pp. 1259-1266.

6) Phipps, C. R., Reilly, J. P. and Campbell, J. W.: Optimum Parameters for Laser Launching Objects into Low Earth Orbit, Laser Particle Beams, 18 (2000), pp. 661-695.

7) Katsurayama, H., Komurasaki, K., Momozawa, A. and Arakawa, Y.: Numerical and Engine Cycle Analyses of a Pulse Laser Ramjet Vehicle, Trans. Japan Soc. Aero. Space Sci. Space Tech. Japan, 1 (2003), pp. 9-16.

8) Kare, T. J.: Modular Laser Optics for HX Laser Launch, Proc. 3rd Int. Symp. on Beamed Energy Propulsion, AIP Conf. Proc., 766 (2005), pp. 128-139.

9) Komurasaki, K., Nakagawa, T., Ohmura, S. and Arakawa, Y.: Energy Transmission in Space Using an Optical Phased Array, Trans. Japan Soc. Aero. Space Sci. Space Tech. Japan, 3 (2005), pp. 7-11.

10) Campbell, J. W.: Project ORION: Orbital Debris Removal Using Ground-Based Sensors and Lasers, NASA TM-108522, 1996.

11) Phipps, C. R., Friedman, H., Gavel, D., Murray, J., Albrecht, G., George, E. V., Ho, C., Priedhorsky, W., Michaelis, M. M. and Reilly, J. P.: ORION: Clearing Near-Earth Space Debris Using a 20-kW, 530-nm, Earth-Based, Repetitively Pulsed Laser, Laser Particle Beams, 14 (1996), pp. 1-4.

12) Libeau, M. A. and Myrabo, L. N.: Combined Theoretical and Experimental Flight Dynamics Investigation of a LaserPropelled Vehicle, AIAA Paper 02-3781, 2002.

13) 葛山 浩, 弘岡靖郎, 小紫公也, 荒川義博:レーザーパルスジェツ 卜のノズル形状と推進性能の数值解析, 日本航空宇宙学会論文集, 53 (2005), pp. 237-240.

14) Sedov, L. I.: Similarity and Dimensional Methods in Mechanics, 10th Ed., CRC Press, Boca Raton, 1993, Chap. 2.

15) Mori, K., Komurasaki, K. and Arakawa, Y.: Energy Transfer from a Laser Pulse to a Blast Wave in Reduced-Pressure Air Atmospheres, J. Appl. Phys., 95 (2004), pp. 5979-5983.

16) Brekke, A.: Physics of the Upper Polar Atmosphere, Praxis Pub., Chichester, 1997, Chap. 3.

17）葛山 浩, 小紫公也, 荒川義博 : レーザー-プラズマエネルギー 変換におけるレーザー支持デトネーション波の一次元モデル , プ ラズマ応用科学 , 12 (2004), pp. 17-22.

18) Raizer, Y. P.: Laser-Induced Discharge Phenomena, Consultants Bureau, New York, 1977, Chap. 6.

19) Wang, T.-S., Chen, Y.-S., Liu, J., Myrabo, L. N. and Mead, F. B. Jr.: Advanced Performance Modeling of Experimental Laser Lightcraft, J. Propul. Power, 18 (2002), pp. 1129-1138.

20) Schall, W. O., Bohn, W. L., Eckel, H.-A., Mayerhofer, W., Riede, W. and Zeyfang, E.: Lightcraft Experiments in Germany, Proc. SPIE: High-Power Laser Ablation III, Vol. 4065, 2000, pp. 472-481.

21) Pirri, A. N., Monsler, M. J. and Nebolsine, P. E.: Propulsion by Absorption of Laser Radiation, AIAA J., 12 (1974), pp. 1254-1261.

22) Ageev, V. P., Barchukov, A. I., Bunkin, F. V., Konov, V. I., 
Korobeinikov, V. P., Putjatin, B. V. and Hudjakov, V. M.: Experimental and Theoretical Modeling of Laser Propulsion, Acta Astronaut., 7 (1980), pp. 79-90.

23) Sasoh, A., Kister, M., Urabe, N. and Takayama, K.: LaserPowered Launch in Tube, Trans. Japan Soc. Aeronaut. Space Sci., 46 (2003), pp. 52-54.

24) Simons, G. A. and Pirri, A. N.: The Fluid Mechanics of Pulsed Laser Propulsion, AIAA J., 15 (1977), pp. 835-842.

25) Katsurayama, H., Ushio, M., Komurasaki, K. and Arakawa, Y.: Analytical Study on Flight Performance of a RP Laser Launcher, Proc. 3rd Int. Symp. on Beamed Energy Propul- sion, AIP Conf. Proc., 766 (2005), pp. 117-127.

26) Detra, R. W., Kemp, N. H. and Riddell, F. R.: Addendum to 'Heat Transfer to Satellite Vehicles Reentering the Atmosphere', Jet Propul., 27 (1957), pp. 1256-1257.

27) 白水正男 : 宇宙往還機の重量評価と感度解析 (关の 1), SSTO 第 1 報, NAL TM-598, 1989 .

28) 白川 晃, 植田憲一: シングルモード Yb 系ファイバーレーザーの 高出力化の現状と動向，レーザー研究 , 33 (2005), pp. 254-261.

29) Richard, J. C., Morales, C. and Myrabo, L. N.: Transatmospheric Laser Propulsion of a 100 MW-Class Lightcraft Technology Demonstrator (LTD), AIAA Paper 88-2970, 1988. 